University of Nebraska - Lincoln

DigitalCommons@University of Nebraska - Lincoln

\title{
Genetic diversity in wild and cultivated black raspberry (Rubus occidentalis L.) evaluated by simple sequence repeat markers
}

\author{
Michael Dossett \\ Pacific Agri-Food Research Centre \\ Nahla V. Bassil \\ United States Department of Agriculture \\ Kim S. Lewers \\ United States Department of Agriculture \\ Chad E. Finn \\ United States Department of Agriculture, Chad.Finn@ars.usda.gov
}

Follow this and additional works at: https://digitalcommons.unl.edu/usdaarsfacpub

Dossett, Michael; Bassil, Nahla V.; Lewers, Kim S.; and Finn, Chad E., "Genetic diversity in wild and cultivated black raspberry (Rubus occidentalis L.) evaluated by simple sequence repeat markers" (2012). Publications from USDA-ARS / UNL Faculty. 1243.

https://digitalcommons.unl.edu/usdaarsfacpub/1243

This Article is brought to you for free and open access by the U.S. Department of Agriculture: Agricultural Research Service, Lincoln, Nebraska at DigitalCommons@University of Nebraska - Lincoln. It has been accepted for inclusion in Publications from USDA-ARS / UNL Faculty by an authorized administrator of DigitalCommons@University of Nebraska - Lincoln. 


\title{
Genetic diversity in wild and cultivated black raspberry (Rubus occidentalis L.) evaluated by simple sequence repeat markers
}

\author{
Michael Dossett • Nahla V. Bassil • \\ Kim S. Lewers · Chad E. Finn
}

This article is a U.S. government work, and is not subject to copyright in the United States.

Received: 7 September 2011/Accepted: 15 January 2012/Published online: 26 February 2012

(C) Springer Science+Business Media Dordrecht (outside the USA) 2012

\begin{abstract}
Breeding progress in black raspberry $(R u$ bus occidentalis L.) has been limited by a lack of genetic diversity in elite germplasm. Black raspberry cultivars have been noted for showing very few phenotypic differences and seedlings from crosses between cultivars for a lack of segregation for important traits. Despite these challenges, little molecular work has been done to explore genetic diversity and relationships in wild and cultivated black raspberry germplasm. Microsatellite, or simple sequence repeat
\end{abstract}

M. Dossett

Corvallis, OR 97331, USA

Present Address:

M. Dossett

Agriculture and Agri-Food Canada, Pacific Agri-Food Research Centre, 6947 \#7 Hwy, Agassiz, BC V0M 1A0, Canada

N. V. Bassil

US Department of Agriculture, Agricultural Research Service, National Clonal Germplasm Repository, 33447

Peoria Road, Corvallis, OR 97333, USA

K. S. Lewers

US Department of Agriculture, Agricultural Research Service, Fruit Laboratory, 10300 Baltimore Avenue, BARC-West Building 010A, Beltsville, MD 20705, USA

C. E. Finn $(\triangle)$

US Department of Agriculture, Agricultural Research Service, Horticultural Crops Research Unit, 3420 NW Orchard Avenue, Corvallis, OR 97330, USA

e-mail: Chad.Finn@ars.usda.gov
(SSR), markers are highly polymorphic codominant markers useful for studying genetic diversity, population genetics, genetic fingerprinting and other applications. We examined genetic diversity in 148 wild and cultivated black raspberry accessions using 21 polymorphic SSR markers. Black raspberry cultivars clustered tightly and showed higher than expected heterozygosity while that of wild accessions was low. Relationships between wild black raspberry accessions were poorly resolved and regional clusters were mostly absent from our analysis. Our results indicated that wild black raspberry germplasm is a relatively untapped resource available for future breeding.

Keywords Blackcap $\cdot$ Microsatellite $\cdot$ Molecular markers $\cdot$ Rubus occidentalis $\cdot$ SSR

\section{Introduction}

The black raspberry, commonly called "blackcap", was first domesticated in the 1830s (Hedrick 1925). A member of the Rosaceae, it is diploid $(2 n=2 x=14)$ and is native to eastern North America from New Brunswick to the Carolinas and west into Kansas and Nebraska. West of the Rockies, it is supplanted by $R$. leucodermis Dougl. ex Torr. et Gray (Hitchcock and Cronquist 1973), which is similar in appearance but with more coarsely toothed leaves, spinier canes, and softer, purplish fruit. Both species are somewhat unusual among diploid members of the subgenus 
Idaeobatus for their self-compatible flowers (Jennings 1988).

Black raspberry production in North America has undergone a slow but steady reduction since the 1920s due in large part to disease and a lack of adapted, disease-resistant cultivars. Today, growers in Oregon, the leading production region, typically see a decline in production after the second harvest and remove fields after only three or four seasons because of decreased profitability (Halgren et al. 2007). At the same time, demand for black raspberry fruit has increased in recent years in large part because of studies outlining the potential health benefits of black raspberry consumption (Kresty et al. 2001; Seeram et al. 2006; Seeram 2008; Stoner et al. 2005, 2008). These factors have combined to create a renewed interest in breeding better cultivars that meet the demands of growers and consumers.

Historically, progress in breeding black raspberry has been limited by a lack of variation and segregation for important traits in elite germplasm. Attempts to broaden the genetic base of black raspberry breeding populations by using other Rubus species date back to the 1950s (Drain 1956; Slate and Klein 1952; Williams 1950). The lack of genetic diversity is so acute that Ourecky (1975) felt that no future progress would be made in breeding black raspberry without the use of other species. However, in contrast to red raspberry, in which interspecific hybridization has played a major role in the introgression of new traits of interest, this approach has been of limited success in black raspberry. 'Earlysweet', released in 1996, is the first, and only, black raspberry cultivar reported to have another species, R. leucodermis, in its background (Galletta et al. 1998).

Few recent studies have attempted to quantify the genetic variation present in black raspberry germplasm. Weber (2003) examined genetic diversity in 14 cultivars and two wild selections from New York using random amplified polymorphic DNA (RAPD) markers. Genetic diversity was quite low; on average, there was $81 \%$ similarity among polymorphic markers, however, more than half of this variability was accounted for by 'Black Hawk', 'Cumberland', 'John Robertson', and the two wild selections. The remaining 11 genotypes had a collective marker similarity of $92 \%$. Weber (2003) asserted that many cultivars that originated as chance seedlings were probably from open pollination of other cultivars. While this work yielded valuable information about the apparent lack of variability and relationships between black raspberry cultivars, RAPD markers lack the reproducibility desired for genetic fingerprinting and large scale population studies. Nybom and Schaal (1990) used restriction fragment length polymorphism (RFLP) markers to document genetic diversity in a wild black raspberry population in Missouri. They found 15 unique genotypes among 20 plants sampled along a $600 \mathrm{~m}$ stretch of roadside, and suggested that the main mode of plant recruitment in this population was through sexually produced seed leading to intrapopulation diversity.

Simple sequence repeat (SSR) or microsatellite markers are robust, highly polymorphic, codominant markers giving them an advantage over RAPD and RFLP markers for applications in population genetics, genetic diversity studies, and DNA fingerprinting. Microsatellite markers have been developed from expressed sequence tag (EST) and genomic libraries in red raspberry (Rubus idaeus L.; Castillo et al. 2010; Graham et al. 2004) and blackberry (Rubus L. subgenus Rubus) (Amsellem et al. 2001; Castillo et al. 2010; Lewers et al. 2008; Lopes et al. 2006). More recently, work to develop SSRs from black raspberry ESTs is underway (unpublished data). Using SSR markers, Dossett et al. (2010) found 12 black raspberry cultivars to be more closely related to each other than to any of the four wild accessions examined. This result, along with those of Weber (2003) and Nybom and Schaal (1990), suggests that wild populations have more genetic diversity than do current cultivars.

Surprisingly, beyond a few selections made in the late 19 th and early 20th centuries, there is little record of the use of wild $R$. occidentalis as a source of genetic diversity for breeding improved black raspberry cultivars, and no record of attempts to systematically collect and evaluate germplasm from across the species' range. Dossett et al. (2008) found increased vigor and adaptability in progeny of a wild black raspberry selection from North Carolina. Dossett and Finn (2010) found aphid resistance in wild black raspberry germplasm, a trait that will be of great benefit in developing new virus resistant cultivars. It appears that wild black raspberry germplasm could be beneficial in developing better adapted and more disease resistant cultivars. The objective of this study was to investigate the level of genetic variation present in wild and cultivated black raspberry. 


\section{Materials and methods}

Plant materials

During the summer of 2006, friends and colleagues in eastern North America, within the native distribution of $R$. occidentalis, were solicited to send seed or fruit from wild plants in their area. Additional seed was obtained in 2007 through a similar request and from collecting trips across the southern and western edges of the native range (Hall et al. 2009; Hummer et al. 2008a, b). Through these efforts, seeds were obtained from more than 150 locations across the range, including 27 states and two Canadian provinces. Upon arrival in the lab, seeds were extracted from the fruit, dried, and stored in a cool dry place until scarification. Additional seed was obtained from $R$. occidentalis seed lots held at the National Clonal Germplasm Repository (NCGR) in Corvallis, OR. Seeds were treated to promote germination using the methods of Dossett and Finn (2010), and a single seedling from each population from which seed was successfully germinated was randomly selected for inclusion in this study. In addition, each of the black raspberry cultivars and wild accessions currently available as clones at the NCGR were included in this study, for a total of 21 cultivars and 137 wild accessions (Table 1, Fig. 1). Naturally occurring hybrids with wild red raspberry (as recognized by their densely spined canes, and differences in leaf shape and leaflet number) were noted in seedlings of a few populations and were deliberately avoided when sampling seedlings for this study. A few plants showing morphology consistent with polyploidy (primarily leaf shape and appearance of leaf venation, see Hull and Britton 1956) were identified in two of the populations and these seedlings were also excluded from sampling for this study. Two wild seedlings of $R$. leucodermis, one from Washington, the other from Oregon, were included for comparison and dendrogram construction, but were not included in measurements of allelic diversity.

DNA extraction and amplification

DNA was extracted from freshly growing young leaf tissue with the Gentra Puregene kit (Qiagen, Valencia, CA) using the optional RNAse A treatment.

Rubus SSR primer sequences were selected from published reports in red raspberry (Graham et al. 2004) and blackberry (Castillo et al. 2010; Lopes et al. 2006; Lewers et al. 2008). Dossett et al. (2010) described the transferability of many of these Rubus SSR primers to black raspberry. These primers, and two previously unreported black raspberry EST SSR primer pairs, are summarized in Table 2. Optimum annealing temperatures was determined by gradient polymerase chain reaction (PCR) from 50 to $65{ }^{\circ} \mathrm{C}$ in 'Munger' using non-fluorescent primers. After an initial denaturation at $94{ }^{\circ} \mathrm{C}$ for $3 \mathrm{~min}$, DNA was amplified for 35 cycles in a PTC-225 gradient thermal cycler (Bio-Rad, Hercules, CA) programmed for a $40 \mathrm{~s}$ denaturation step at $94{ }^{\circ} \mathrm{C}$, a $40 \mathrm{~s}$ annealing step at the optimum annealing temperature of the primer pair and a $40 \mathrm{~s}$ extension step at $72{ }^{\circ} \mathrm{C}$. A final extension step at $72{ }^{\circ} \mathrm{C}$ for $30 \mathrm{~min}$ was included. Non-fluorescent PCR reactions were performed in a volume of $10 \mu \mathrm{l}$ and bands visualized by ethidium bromide staining after separation by $2 \%$ agarose gel electrophoresis. PCR was then performed on all samples with fluorescently labeled (WellRed D2, D3, or D4) forward primers at the appropriate annealing temperature in a volume of $15 \mu \mathrm{l}$. For some SSRs, instead of fluorescently labeling all forward primers, the M13 sequence TGTAAAACGACGGCCAGT was added to the $5^{\prime}$ end of the forward primer (Table 2) and a fluorescently labeled (WellRed D2, D3, or D4; Integrated DNA Technologies, Inc. Coralville, IA) M13 primer was used in the PCR, following the procedure outlined by Schuelke (2000). Fluorescently labeled PCR products were separated by capillary electrophoresis using a Beckman CEQ 8000 genetic analyzer (Beckman Coulter, Fullerton, California) for all samples. The reverse primer for Rub1C6 was pigtailed (Brownstein et al. 1996) to minimize the occurrence of split peaks and difficulties encountered in fragment analysis following capillary electrophoresis.

\section{Data analysis}

The data were compiled and analyzed with PowerMarker (Liu and Muse 2005). Expected and observed heterozygosity $\left(\mathrm{H}_{\mathrm{e}}, \mathrm{H}_{\mathrm{o}}\right.$, Nei 1987) and polymorphism information content (PIC, Botstein et al. 1980; Liu 1998) were estimated for all black raspberry genotypes together, as well as separately for cultivated and wild genotypes. A neighbor-joining (NJ) dendrogram (Fig. 2) was constructed based on the proportion of shared alleles distance measure (Bowcock et al. 1994). 
Table 1 US Department of Agriculture- Agricultural Research Service plant introduction (PI) number, accession name, origin, and type, for 137 wild and 21 cultivated Rubus occidentalis and two $R$. leucodermis accessions studied

\begin{tabular}{|c|c|c|}
\hline PI no. & Name & Origin \\
\hline \multicolumn{3}{|c|}{ Wild accessions } \\
\hline 653296 & ORUS 4123 & Mentone, $\mathrm{AL}$ \\
\hline 653327 & ORUS 3779 & Litchfield County, CT \\
\hline 652978 & HDF-039 & Appalachian Trail, GA \\
\hline 652975 & ORUS 4117 & Clayton, GA \\
\hline 652976 & ORUS 4119 & Clayton, GA \\
\hline 653294 & ORUS 4120 & Clayton, GA \\
\hline 653298 & ORUS 4122 & Dahlonega, GA \\
\hline 652977 & ORUS 4121 & Union County, GA \\
\hline 653328 & ORUS 3780 & Story County, IA \\
\hline $\mathrm{NA}^{\mathrm{a}}$ & ORUS 3789 & Arenzeville, IL \\
\hline 653329 & ORUS 3781 & Iroquois County, IL \\
\hline 553949 & ORUS 3946 & Waukegan County, IL \\
\hline 553949 & CRUB 641.002 & Waukegan County, IL \\
\hline 553950 & CRUB 642.001 & Waukegan County, IL \\
\hline 653331 & ORUS 3796 & Greene County, IN \\
\hline 653335 & ORUS 3800 & Greene County, IN \\
\hline 653332 & ORUS 3797 & Hendricks County, IN \\
\hline 653330 & ORUS 3794 & Putnam County, IN \\
\hline 653333 & ORUS 3798 & Sullivan County, IN \\
\hline NA & ORUS 3795 & Vigo County, IN \\
\hline 653334 & ORUS 3799 & Vigo County, IN \\
\hline 653336 & ORUS 3801 & Southern IN \\
\hline 652984 & ORUS 4126 & Alma, KS \\
\hline 653299 & ORUS 4124 & Bonner Springs, KS \\
\hline 653303 & ORUS 4129 & Fort Riley, KS \\
\hline 653301 & ORUS 4127 & Manhattan, KS \\
\hline 651846 & ORUS 4130 & Minneapolis, KS \\
\hline 653302 & ORUS 4128 & Ogden, KS \\
\hline 653300 & ORUS 4125 & Perry Lake, KS \\
\hline 651848 & ORUS 3802 & Fayette County, KY \\
\hline 653337 & ORUS 3803 & Berkshire County, MA \\
\hline 653338 & ORUS 3804 & Berkshire County, MA \\
\hline 653343 & ORUS 3811 & Allegany County, MD \\
\hline 653344 & ORUS 3812 & Anne Arundel County, MD \\
\hline NA & ORUS 3809 & Dorchester County, MD \\
\hline 653341 & ORUS 3808 & Harford County, MD \\
\hline 653342 & ORUS 3810 & Howard County, MD \\
\hline NA & ORUS 3806 & Howard County, MD \\
\hline 653339 & ORUS 3805 & Washington County, MD \\
\hline 653340 & ORUS 3807 & Washington County, MD \\
\hline 653350 & ORUS 3821 & Camden, ME \\
\hline 653349 & ORUS 3820 & East Vassalboro, ME \\
\hline 653347 & ORUS 3817 & Gardiner, ME \\
\hline 653348 & ORUS 3819 & Hallowell, ME \\
\hline
\end{tabular}


Table 1 continued

\begin{tabular}{|c|c|c|}
\hline PI no. & Name & Origin \\
\hline 651849 & ORUS 3815 & Monmouth, ME \\
\hline 653345 & ORUS 3814 & Orono, ME \\
\hline 653346 & ORUS 3816 & West Kennebunk, ME \\
\hline NA & ORUS 4109 & Bath, MI \\
\hline NA & ORUS 4110 & Benton Harbor, MI \\
\hline 553765 & ORUS 3948 & Fred Russ State Forest, MI \\
\hline 553766 & ORUS 3949 & Fred Russ State Forest, MI \\
\hline NA & ORUS 4111 & Grand Ledge, MI \\
\hline 553764 & ORUS 3947 & Oak Grove, MI \\
\hline NA & ORUS 4112 & Okemos, MI \\
\hline 653323 & ORUS 4149 & Belgrade, MN \\
\hline 653321 & ORUS 4148 & Big Stone Lake National Wildlife Refuge, MN \\
\hline 651847 & ORUS 4147 & Big Stone Lake State Park, MN \\
\hline 653351 & ORUS 3823 & Cass County, MN \\
\hline 651851 & ORUS 3827 & Dakota County, MN \\
\hline 653354 & ORUS 3828 & Dakota County, MN \\
\hline 653324 & ORUS 4150 & Hasty, MN \\
\hline 651850 & ORUS 3824 & Ramsey County, MN \\
\hline 653353 & ORUS 3826 & Ramsey County, MN \\
\hline NA & ORUS 3833 & Cassville, MO \\
\hline 651852 & ORUS 3830 & Fordland, MO \\
\hline 653356 & ORUS 3832 & Fordland, MO \\
\hline 653357 & ORUS 3835 & Madison County, NC \\
\hline 653358 & ORUS 3837 & Rutherford County, NC \\
\hline 653359 & ORUS 3838 & Rutherford County, NC \\
\hline 553755 & NC 84-10-3 & Zebulon, NC \\
\hline 653311 & ORUS 4139 & Chadron, NE \\
\hline 653310 & ORUS 4138 & Chadron State Park, NE \\
\hline 653308 & ORUS 4136 & Halsey, NE \\
\hline 618482 & CRUB 1732.001 & Nebraska City, NE \\
\hline 653305 & ORUS 4133 & North Loup State Recreation Area, NE \\
\hline 653306 & ORUS 4134 & Pibel Lake State Recreation Area, NE \\
\hline 653309 & ORUS 4137 & Valentine, NE \\
\hline 653307 & ORUS 4135 & Victoria Springs State Recreation Area, NE \\
\hline 638243 & ORUS 3955 & Manasquan Reservoir, NJ \\
\hline 638244 & ORUS 3956 & Tom's River, NJ \\
\hline 653363 & ORUS 3843 & Columbia County, NY \\
\hline 653362 & ORUS 3842 & Dutchess County, NY \\
\hline 653360 & ORUS 3839 & Ontario County, NY \\
\hline 653361 & ORUS 3840 & Ontario County, NY \\
\hline NA & ORUS 3841 & Ontario County, NY \\
\hline 618560 & ORUS 3951 & Poughkeepsie, NY \\
\hline 653364 & ORUS 3844 & Yates County, NY \\
\hline 653368 & ORUS 3849 & Clermont County, OH \\
\hline NA & ORUS 4107 & Hilliard, $\mathrm{OH}$ \\
\hline
\end{tabular}


Table 1 continued

\begin{tabular}{|c|c|c|}
\hline PI no. & Name & Origin \\
\hline NA & ORUS 4108 & Newton Falls, OH \\
\hline 653372 & ORUS 3854 & Centre County, PA \\
\hline 653373 & ORUS 3856 & Centre County, PA \\
\hline 653369 & ORUS 3851 & Chester County, PA \\
\hline 653370 & ORUS 3852 & Greene County, PA \\
\hline 653371 & ORUS 3853 & Somerset County, PA \\
\hline NA & ORUS 4185 & Charlestown, RI \\
\hline 652971 & ORUS 4113 & Glassy Mountain, SC \\
\hline 652973 & ORUS 4114 & Glassy Mountain, SC \\
\hline 652974 & ORUS 4115 & Rich Mountain, SC \\
\hline 653315 & ORUS 4142 & Clay County State Park, SD \\
\hline 653318 & ORUS 4145 & East Sioux Falls, SD \\
\hline 653317 & ORUS 4144 & Newton Hills State Park, SD \\
\hline 653319 & ORUS 4146 & Oakwood Lakes State Park, SD \\
\hline 652988 & ORUS 4140 & Pease Creek State Recreation Area, SD \\
\hline 653316 & ORUS 4143 & Union Grove State Park, SD \\
\hline 653314 & ORUS 4141 & Yankton, SD \\
\hline 653389 & ORUS 3904 & Cannon County, TN \\
\hline 653395 & ORUS 3915 & Cheatham County, TN \\
\hline 653374 & ORUS 3857 & Davidson County, TN \\
\hline 653375 & ORUS 3863 & Davidson County, TN \\
\hline 653376 & ORUS 3864 & Davidson County, TN \\
\hline 618286 & NC 98-12-1 & DeKalb County, TN \\
\hline 653377 & ORUS 3867 & DeKalb County, TN \\
\hline 653378 & ORUS 3869 & DeKalb County, TN \\
\hline 653379 & ORUS 3871 & DeKalb County, TN \\
\hline 653380 & ORUS 3873 & DeKalb County, TN \\
\hline 653381 & ORUS 3878 & DeKalb County, TN \\
\hline 653384 & ORUS 3889 & Grundy County, TN \\
\hline 653385 & ORUS 3893 & Grundy County, TN \\
\hline 653398 & ORUS 3919 & Henderson County, TN \\
\hline 618287 & NC 98-7-1 & Roane County, TN \\
\hline 653396 & ORUS 3916 & Unicoi County, TN \\
\hline 653397 & ORUS 3918 & Unicoi County, TN \\
\hline 653382 & ORUS 3883 & Van Buren County, TN \\
\hline 653390 & ORUS 3906 & Van Buren County, TN \\
\hline 653392 & ORUS 3910 & Van Buren County, TN \\
\hline 653393 & ORUS 3911 & Van Buren County, TN \\
\hline 653394 & ORUS 3912 & Van Buren County, TN \\
\hline 653383 & ORUS 3884 & Warren County, TN \\
\hline 653386 & ORUS 3898 & Warren County, TN \\
\hline 653387 & ORUS 3902 & Warren County, TN \\
\hline 653399 & ORUS 3926 & Columbia County, WI \\
\hline 653401 & ORUS 3930 & Inwood, WV \\
\hline 653402 & ORUS 3931 & Preston County, WV \\
\hline
\end{tabular}


Table 1 continued

\begin{tabular}{|c|c|c|c|}
\hline & \multirow{2}{*}{$\frac{\text { PI no. }}{653400}$} & \multirow{2}{*}{$\begin{array}{l}\text { Name } \\
\text { ORUS } 3929\end{array}$} & \multirow{2}{*}{$\begin{array}{l}\text { Origin } \\
\text { Shepherdstown, WV }\end{array}$} \\
\hline & & & \\
\hline & 653325 & ORUS 3777 & Mactaquac, NB, Canada \\
\hline & 653326 & ORUS 3778 & Simcoe, ON, Canada \\
\hline & NA & ORUS 4150 & R. leucodermis-Mt. Rainier National Park, WA \\
\hline & 553680 & CRUB 647.001 & R. leucodermis-Curry County, OR \\
\hline (a) & \multicolumn{3}{|l|}{ Cultivars } \\
\hline & 553733 & 'Allen' & 'Bristol' $\times$ 'Cumberland', 1957 \\
\hline & 553734 & 'Black Hawk' & 'Quillan' × 'Black Pearl', 1955 \\
\hline & 553754 & 'Black Knight' & 'Johnson Everbearing selfed', 1973 \\
\hline & 553735 & 'Bristol' & 'Watson Prolific' $\times$ 'Honeysweet', 1934 \\
\hline & 553739 & 'Cumberland' & Wild selection from Pennsylvania, 1890s \\
\hline & 553770 & 'Dundee' & 'Smith1' × 'Palmer', 1927 \\
\hline & 657877 & 'Earlysweet' & ('Haut' $\times$ R. leucodermis) $\times$ open-pollinated, 1996 \\
\hline & 553773 & 'Ebonee' & 'Cumberland' $\times$ open-pollinated, 1961 \\
\hline & 658341 & 'Explorer' & Wild parents from New York and Arkansas, 2004 \\
\hline & 553768 & 'Hanover' & Unknown, perhaps from Indiana \\
\hline & 553769 & 'Haut' & 'Manteo' selfed $\times$ 'Bristol' selfed, 1987 \\
\hline & 553742 & ‘Jewel' & ('Bristol' $\times$ 'Dundee') $\times$ 'Dundee', 1973 \\
\hline & 553736 & 'Huron' & 'Rachel' × 'Dundee', 1965 \\
\hline & 553772 & 'John Robertson' & Wild selection from near Hot Springs, SD, 1934 \\
\hline & 618387 & 'Mac Black' & Unknown \\
\hline & 553740 & 'Munger' & Reputed to be 'Schaefer' open-pollinated \\
\hline a Accessions not yet & 553741 & 'New Logan’ & Unknown wild parentage \\
\hline available through the & 553737 & 'Plum Farmer' & Chance seedling from Ohio, 1892 \\
\hline $\begin{array}{l}\text { USDA, ARS, National } \\
\text { Genetic Resources }\end{array}$ & 553738 & 'Shuttleworth' & Developed in New York, 1933 \\
\hline Program, Germplasm & 618505 & ‘Somo’’ & Unknown, from wild parents, 1956 \\
\hline $\begin{array}{l}\text { Resources Information } \\
\text { Network (GRIN) }\end{array}$ & 618458 & 'White Chimera' & Sport of a 'Munger' seedling, 1993 \\
\hline
\end{tabular}

A separate NJ dendrogram was constructed from a cluster within the UPGMA tree comprised of most black raspberry cultivars and a few wild black raspberry accessions (Fig. 3). The bootstrap option of PowerMarker was used to create 1,000 dendrograms and MEGA version 4 software (Tamura et al. 2007) was used to generate and edit a consensus dendrogram. Principal component analysis (PCA) was performed using a similarity matrix based on Euclidean distances with NTSYS-pc (version 2.1; Exeter Software, Setauket, NY).

\section{Results and discussion}

Twenty-one SSR primer pairs amplified one or two alleles in each of the 21 cultivated and 125 wild $R$. occidentalis accessions. In 12 additional wild accessions, more than two alleles were amplified by one or more of the primer pairs studied. This may be the result of introgression of alleles from red raspberry or other Rubus species, duplication of some genome regions, or polyploidy. Individuals amplifying more than two alleles for any primer pair (ORUS 3779, ORUS 3789, ORUS 3795, ORUS 3803, ORUS 3823 , ORUS 3827, ORUS 3910, ORUS 4111, ORUS 4122, ORUS 4141, ORUS 4142, and ORUS 4147) were excluded from the analysis and the remaining data were treated as though each SSR primer pair amplified a single locus.

Allelic diversity among the 21 black raspberry cultivars was very low, with three or fewer alleles present at 15 of 21 loci, and only a single locus having more than four alleles present (Table 3). The 21 SSR 
Fig. 1 Geographical distribution of 137 wild Rubus occidentalis populations surveyed

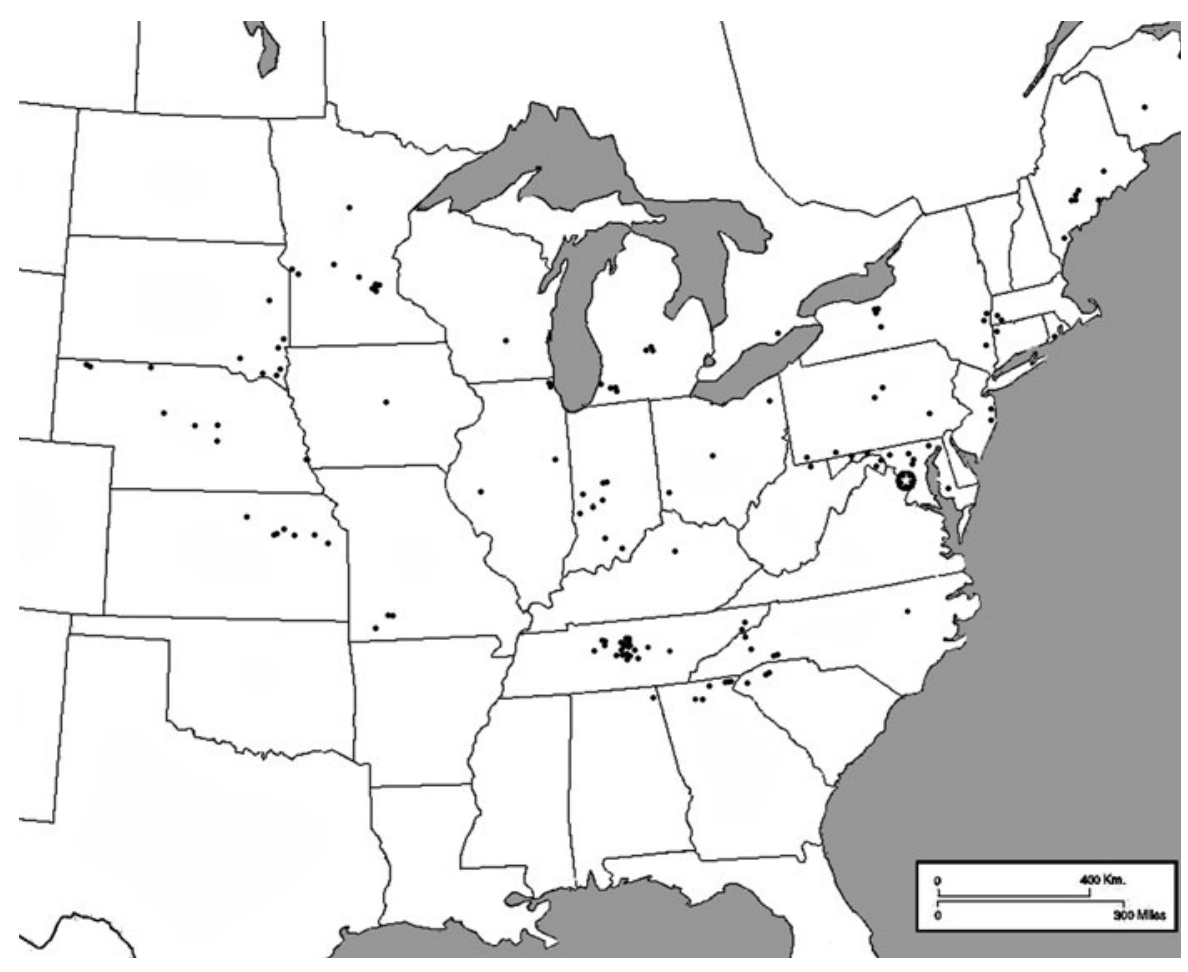

loci were unable to distinguish between six of the cultivars: Bristol, Cumberland, Munger, New Logan, Plum Farmer, and Shuttleworth (Fig. 3). This is in contrast to previous work (Dossett et al. 2010) that found differences between some of these cultivars using 19 of the same SSRs. During the course of this study, we found that differences in primer stocks led to some fragments having been incorrectly sized in a subset of the data from Dossett et al. (2010). Once this problem was discovered, PCRs for samples at the suspect loci were repeated and the correct alleles were verified. The most recently named cultivar of this group (Bristol) was released nearly 80 years ago, and it is possible that mislabeling of plants at some point in the past led to this result. While Hedrick (1925) considered several of these clones to be distinct, Ourecky (1975) noted difficulty in distinguishing between black raspberry cultivars as well as a lack of segregation for important traits in black raspberry seedlings. This may have been due in part to identical clones being evaluated under different names. Alternatively, it is possible that these genotypes may be distinct but cannot be distinguished with existing SSR markers. Using RAPD markers, Weber (2003) was able to distinguish between each of the 14 black raspberry cultivars examined. In that study, 'Bristol', 'Munger', 'New Logan', and 'Plum Farmer' had very high marker similarity (average $=97 \%$ ); 'Cumberland' was somewhat less similar (average 86\% similarity); and 'Shuttleworth' was not included. It is unlikely that the differences observed by Weber (2003) can be attributed solely to the lack of reproducibility of RAPD markers that has been previously noted (Büscher et al. 1993; Jones et al. 1997; MacPherson et al. 1993). In either case, our data highlights the need for better genomic resources and markers to reliably distinguish between closely related black raspberry genotypes, as well as a need for greater genetic diversity in material used in breeding. Further study will be needed to determine whether there are real performance differences between these six clones in the field. Clones from alternate sources should also be fingerprinted. Unfortunately, 'New Logan', 'Plum Farmer', and 'Shuttleworth' are no longer widely available and may be among the many black raspberry cultivars that have been lost over the last 100 years.

Based on the similarity of their alleles, the majority of black raspberry cultivars clustered tightly in one relatively well-defined group in the NJ dendrogram 


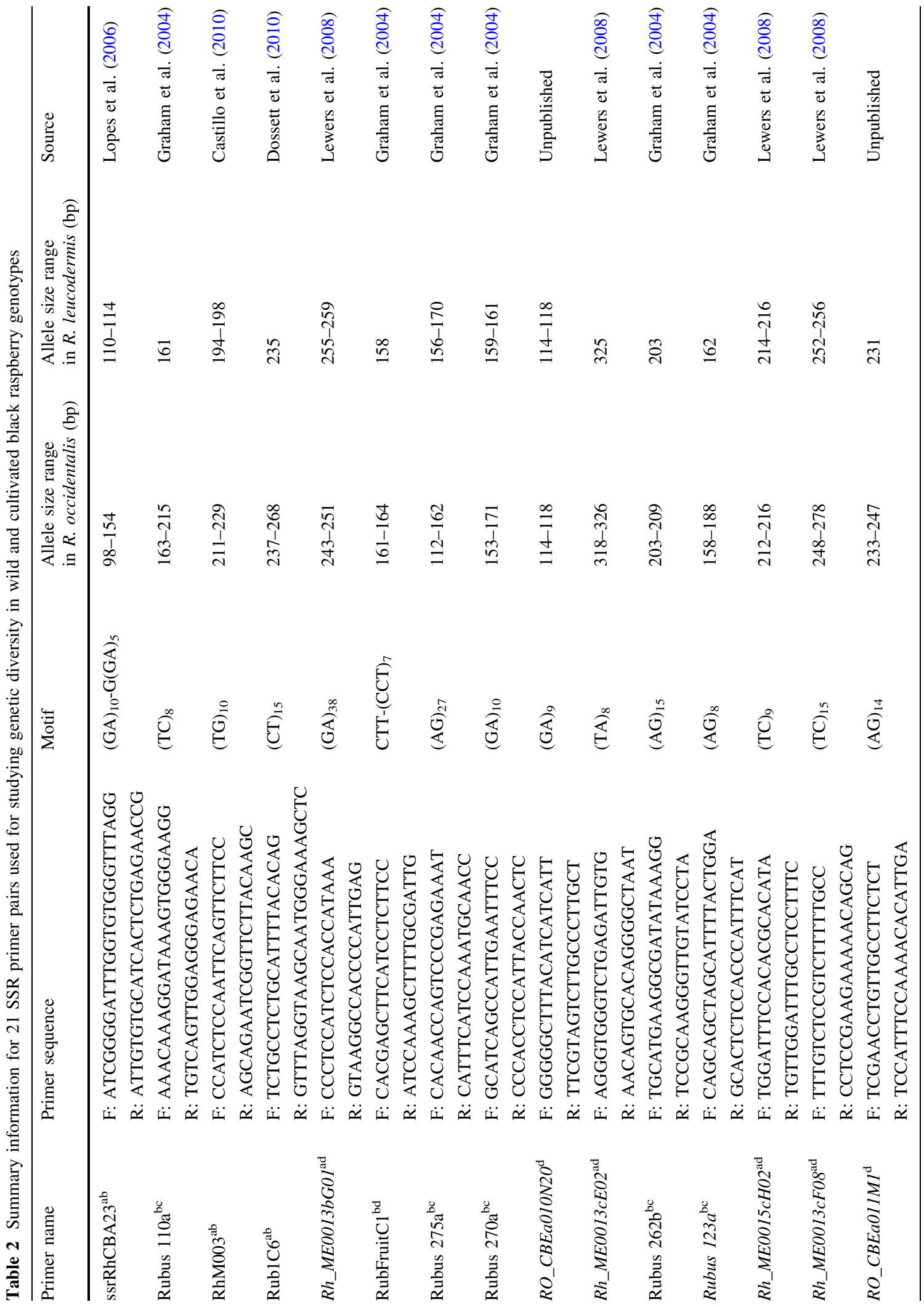




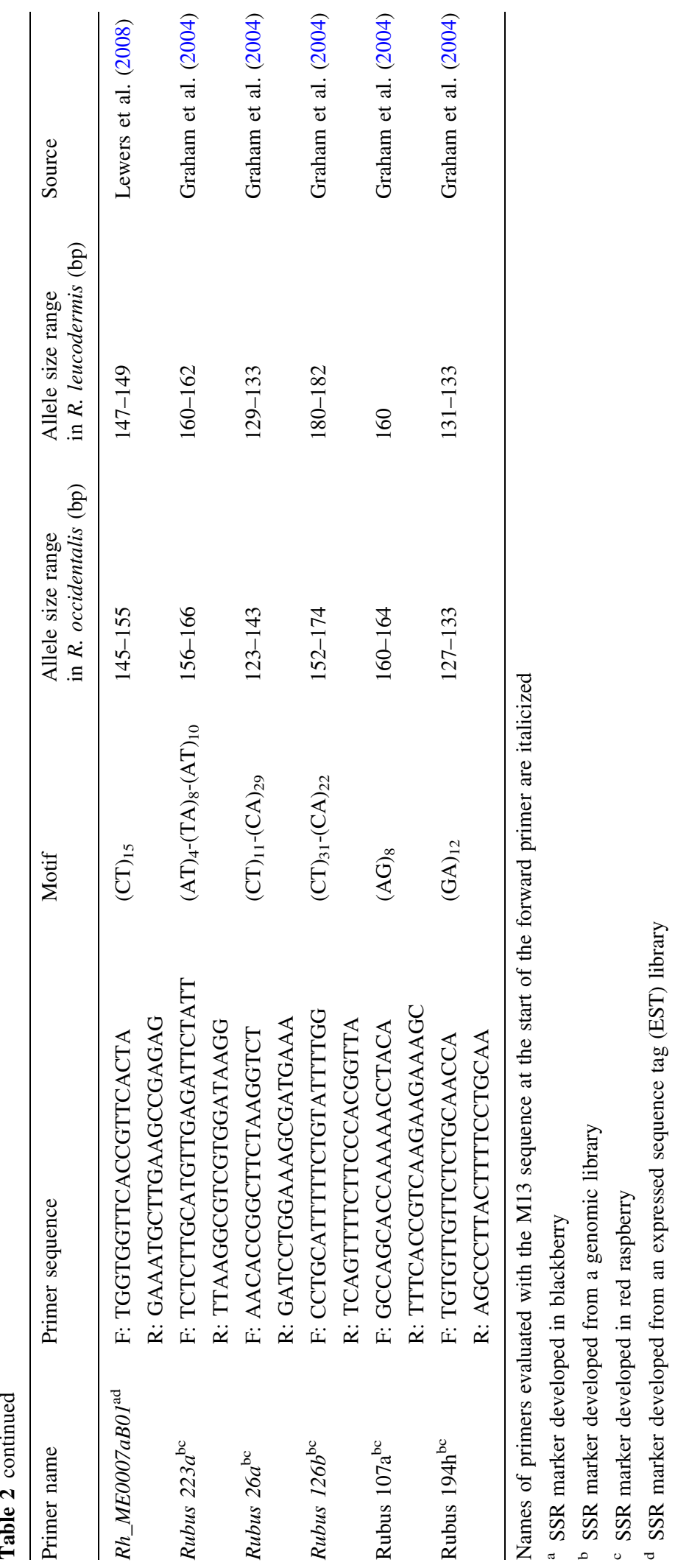




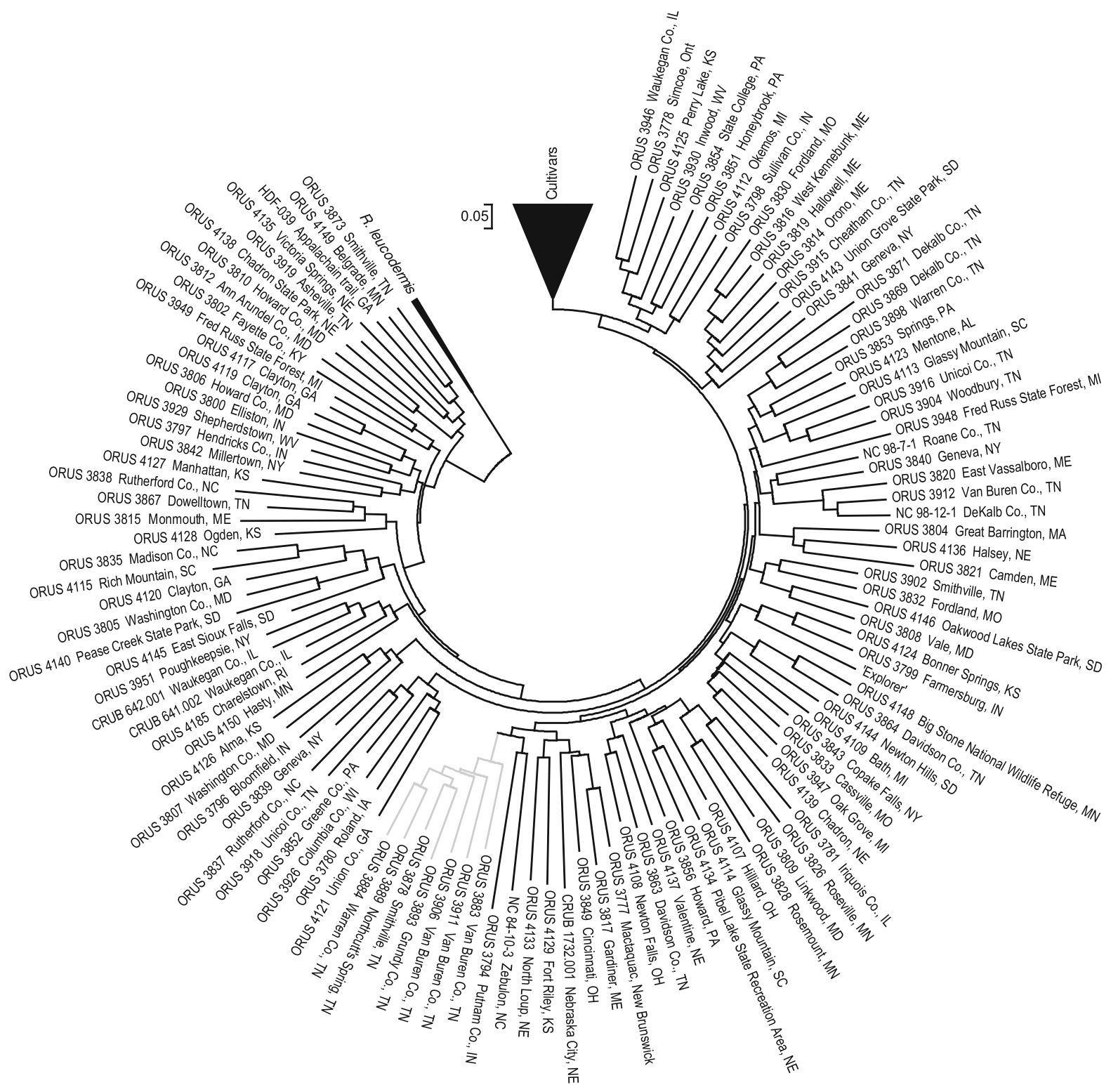

Fig. 2 Neighbor-joining (NJ) dendrogram depicting all black raspberry genotypes studied. A cluster containing most black raspberry cultivars and a few wild accessions has been collapsed

(Fig. 2). The average branch length (distance of shared alleles) separating all of the black raspberry cultivars was 0.26 . A NJ dendrogram depicting the genotypes within this group also shows good bootstrap support for several of the pairings (Fig. 3). 'Explorer', the one cultivar falling outside of this group, was selected from crosses of wild plants from New York and Arkansas for its unusual fall-fruiting habit (Tallman 2007) and was therefore not expected to show a and is depicted in Fig. 3. Branches for a cluster of seven accessions from Tennessee, discussed in the text, are depicted in a lighter shade of gray

close relationship to the other cultivars. Within the cluster of 20 cultivars (Fig. 3), there were also 10 wild black raspberry accessions (ORUS 3801, ORUS 3811, ORUS 3824, ORUS 3844, ORUS 3857, ORUS 3931, ORUS 3955, ORUS 3956, ORUS 4110, and ORUS 4130), some of which consistently paired with cultivars (e.g. ORUS 3956 with 'Jewel'). With the exception of ORUS 3811, and ORUS 3931, which was noted in the field for its distinct morphology, each 


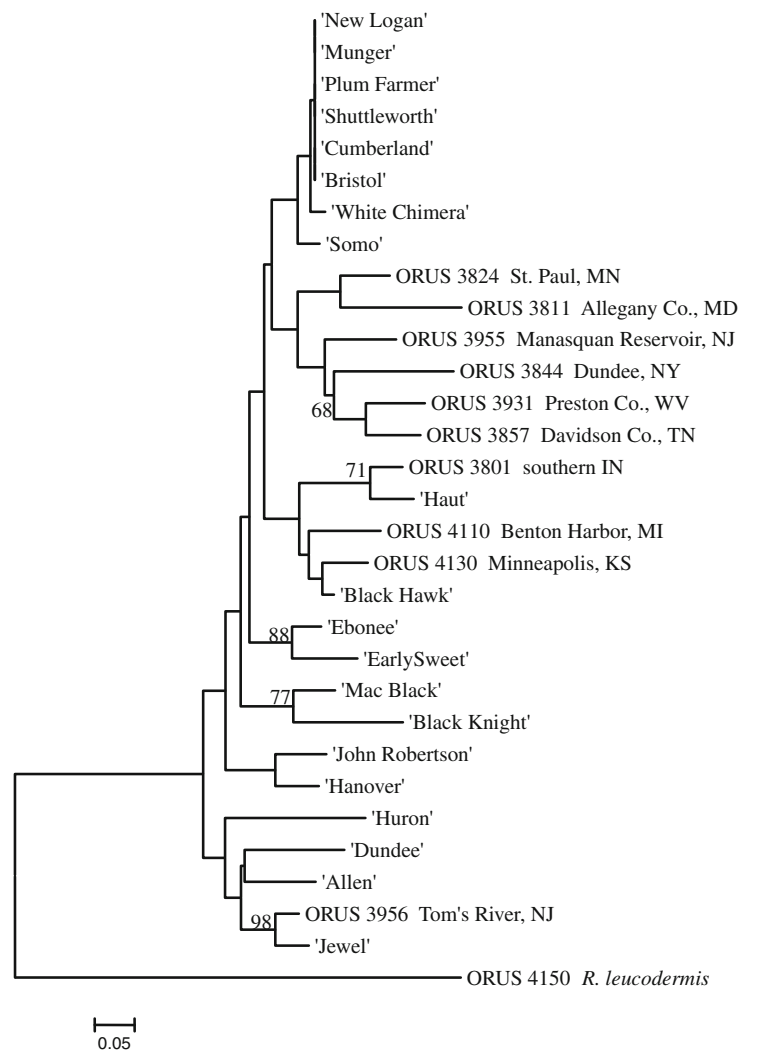

Fig. 3 Neighbor-joining dendrogram of black raspberry cultivars and closely paired wild accessions from a condensed cluster in Fig. 2. Numbers near nodes show bootstrap support for pairings (percent of 1,000 trees). One accession of $R$. leucodermis was used to root the dendrogram

of these had larger than average fruit and/or came from seed lots that segregated for plants lacking the normal waxy, glaucous bloom on their canes (data not shown). Dossett (2007) noted segregation for non-glaucous canes in progeny of some black raspberry cultivars, and the presence of one or both of these traits in these populations suggests that they may be derived from escaped cultivated germplasm.

Despite the low allelic diversity found among black raspberry cultivars, novel alleles not found in the wild genotypes were present at three loci (Table 3). Further examination revealed discrepancies between SSR fingerprint and the stated pedigrees of some cultivars. The published pedigree of 'Jewel' is ('Bristol' $\times$ 'Dundee') $\times$ 'Dundee'. However, in our study, 'Jewel' had alleles at multiple SSR loci that are not carried by either 'Bristol' or 'Dundee' (as illustrated by 112 at ssrRhcBA23 and 169 at Rubus110a, Table 4).
This indicates that either the published pedigree is incorrect, or the identity of the 'Jewel', 'Dundee', or 'Bristol' used in this study is incorrect (Table 4). 'Jewel' and 'Huron' ('Rachel' $\times$ 'Dundee') were the only two individuals sharing a $112 \mathrm{bp}$ allele at ssrRhCBA23, the most polymorphic locus in this study (Table 4), suggesting that either 'Huron' or 'Rachel' may be an ancestor of 'Jewel'. The identity of 'Huron' in this study also does not match its reported pedigree as it does not share an allele with 'Dundee' at Rubus 275a (Table 4). 'Allen' ('Bristol' $\times$ 'Cumberland') and 'Haut' [('Cumberland' selfed $\times$ selfed $) \times$ 'Bristol' selfed] also have alleles that cannot be traced to either of their reported parents (as shown by 158 at Rubus126b for 'Allen' and 128 at Rubus275a and 187 at Rubus110a for 'Haut', Table 4). 'Haut' and 'Huron' were the only two cultivars sharing a $128 \mathrm{bp}$ allele for Rubus 275a (Table 4).

Similarly, 'Earlysweet' is reported to have $R$. leucodermis as one of its grandparents (Galletta et al. 1998). Alleles observed in the two R. leucodermis accessions fell outside the size range of $R$. occidentalis at seven loci (Table 2) and were unique to R. leucodermis at six other loci where there was size overlap (data not shown). While only two $R$. leucodermis genotypes were available in this study for comparison, SSR alleles found in 'Earlysweet' were characteristic of $R$. occidentalis cultivars at every locus, and alleles in the size range of $R$. leucodermis were not observed. This, combined with its close clustering within the group of other cultivars, suggests that 'Earlysweet' may not be one quarter $R$. leucodermis as reported. 'Earlysweet' [('Haut' $\times$ R. leucodermis $) \times$ open-pollinated] may have instead originated from contamination of the pollen used in the cross, or from contamination of the open-pollinated seed lot. In this study, 'Earlysweet' grouped closely with 'Ebonee' ('Cumberland' open-pollinated), possibly due to shared alleles from 'Cumberland', a common ancestor. 'Earlysweet' and 'Dundee' were the only two individuals in the study with a 188 bp allele at Rubus 123a, indicating that 'Dundee' may be a parent of 'Earlysweet' (Table 4). This close relationship is also supported by RAPD markers (Weber 2003). Similarly, 'Mac Black' and 'Black Knight' were the only two individuals that shared a 209 bp allele at Rubus 262b (Table 4). While the pedigree of 'Mac Black' is unknown, 'Black Knight' ('Johnson Everbearing' selfed) predates 'Mac Black' by about 20 years and may be in its lineage. Because of its 
Table 3 Allelic diversity, expected heterozygosity $\left(\mathrm{H}_{\mathrm{e}}\right)$, observed heterozygosity $\left(\mathrm{H}_{\mathrm{o}}\right)$ and polymorphism information content (PIC) for 21 Rubus SSR primer pairs in 21 cultivars and 125 wild $R$. occidentalis accessions

\begin{tabular}{|c|c|c|c|c|c|c|c|c|c|c|c|c|}
\hline \multirow[t]{2}{*}{ Primer name } & \multicolumn{4}{|c|}{ Cultivars $(\mathrm{n}=21)$} & \multicolumn{4}{|c|}{ Wild accessions $(n=125)$} & \multicolumn{4}{|c|}{ All genotypes $(n=146)$} \\
\hline & Allele \# & $\mathrm{H}_{\mathrm{e}}$ & $\mathrm{H}_{\mathrm{o}}$ & PIC & Allele \# & $\mathrm{H}_{\mathrm{e}}$ & $\mathrm{H}_{\mathrm{o}}$ & PIC & Allele \# & $\mathrm{He}$ & Ho & PIC \\
\hline ssrRhCBA23 & 3 & 0.54 & 0.67 & 0.44 & 23 & 0.91 & 0.35 & 0.90 & 24 & 0.90 & 0.40 & 0.89 \\
\hline Rubus 110a & 4 & 0.68 & 0.76 & 0.63 & 22 & 0.88 & 0.32 & 0.87 & 22 & 0.88 & 0.38 & 0.87 \\
\hline RhM003 & 3 & 0.56 & 0.81 & 0.49 & 6 & 0.47 & 0.22 & 0.42 & 6 & 0.52 & 0.31 & 0.45 \\
\hline Rub1C6 & 4 & 0.57 & 0.71 & 0.50 & 18 & 0.90 & 0.41 & 0.90 & 18 & 0.89 & 0.45 & 0.88 \\
\hline Rh_ME0013bG01 & 2 & 0.13 & 0.14 & 0.12 & 3 & 0.23 & 0.08 & 0.21 & 3 & 0.22 & 0.09 & 0.20 \\
\hline RubFruitC1 & 2 & 0.24 & 0.29 & 0.21 & 2 & 0.23 & 0.10 & 0.20 & 2 & 0.23 & 0.13 & 0.20 \\
\hline Rubus $275 a$ & 5 & 0.66 & 0.76 & 0.60 & 20 & 0.91 & 0.35 & 0.90 & 20 & 0.90 & 0.41 & 0.89 \\
\hline Rubus 270a & 2 & 0.44 & 0.57 & 0.35 & 9 & 0.78 & 0.23 & 0.74 & 9 & 0.77 & 0.28 & 0.73 \\
\hline RO_CBEa010N20 & 2 & 0.17 & 0.19 & 0.16 & 2 & 0.39 & 0.16 & 0.31 & 2 & 0.36 & 0.16 & 0.30 \\
\hline Rh_ME0013cE02 & 3 & 0.50 & 0.67 & 0.40 & 5 & 0.56 & 0.17 & 0.46 & 5 & 0.55 & 0.24 & 0.45 \\
\hline Rubus $262 b$ & 2 & 0.09 & 0.10 & 0.09 & 1 & 0.00 & 0.00 & 0.00 & 2 & 0.01 & 0.01 & 0.01 \\
\hline Rubus 123a & 2 & 0.09 & 0.10 & 0.09 & 4 & 0.51 & 0.21 & 0.41 & 5 & 0.49 & 0.19 & 0.39 \\
\hline Rh_ME0015cH02 & 1 & 0.00 & 0.00 & 0.00 & 3 & 0.10 & 0.07 & 0.09 & 3 & 0.09 & 0.06 & 0.08 \\
\hline Rh_ME0013cF08 & 4 & 0.48 & 0.52 & 0.43 & 16 & 0.81 & 0.32 & 0.79 & 16 & 0.78 & 0.35 & 0.76 \\
\hline RO_CBEa011M11 & 3 & 0.48 & 0.57 & 0.38 & 5 & 0.61 & 0.19 & 0.54 & 5 & 0.61 & 0.25 & 0.55 \\
\hline Rh_ME0007aB01 & 4 & 0.54 & 0.62 & 0.44 & 6 & 0.57 & 0.27 & 0.52 & 6 & 0.57 & 0.32 & 0.52 \\
\hline Rubus 223a & 1 & 0.00 & 0.00 & 0.00 & 6 & 0.54 & 0.25 & 0.51 & 6 & 0.48 & 0.21 & 0.46 \\
\hline Rubus 26a & 4 & 0.64 & 0.86 & 0.57 & 9 & 0.71 & 0.22 & 0.66 & 9 & 0.70 & 0.32 & 0.65 \\
\hline Rubus $126 b$ & 3 & 0.56 & 0.67 & 0.49 & 10 & 0.66 & 0.30 & 0.62 & 10 & 0.66 & 0.36 & 0.61 \\
\hline Rubus 107a & 1 & 0.00 & 0.00 & 0.00 & 3 & 0.10 & 0.04 & 0.10 & 3 & 0.09 & 0.03 & 0.08 \\
\hline Rubus $194 \mathrm{~h}$ & 2 & 0.17 & 0.19 & 0.16 & 5 & 0.46 & 0.14 & 0.38 & 5 & 0.43 & 0.15 & 0.36 \\
\hline Mean & 2.7 & 0.36 & $0.44 * * *$ & 0.31 & 8.5 & 0.54 & $0.21 * * *$ & 0.5 & 8.6 & 0.53 & $0.24 * * *$ & 0.49 \\
\hline
\end{tabular}

*** Significant at $P \leq 0.0001$

erect growth habit and very late fruit maturity, as compared to other black raspberry cultivars, there has been speculation that 'Mac Black' may have $R$. idaeus in its ancestry (Makielski, personal communication). However, SSR alleles in 'Mac Black' were characteristic of $R$. occidentalis, matching those found in other cultivars at every locus. This, along with its clustering with the other black raspberry cultivars, casts some doubt on this hypothesis.

Simple sequence repeat analysis also revealed a surprising level of heterozygosity in black raspberry cultivars. At every polymorphic SSR locus examined, observed heterozygosity in the cultivars was higher than expected. This shouldn't be a big surprise since the process of selection and breeding, particularly in a clonally propagated crop such as black raspberry, can lead to highly heterozygous breeding populations. What is slightly surprising, however, is that this heterozygosity has been maintained despite some level of inbreeding in a few cultivars that should lead to a loss of heterozygosity. While pedigree information is missing or sparse for many cultivars, several are known to be parents and/or grandparents of others and to have related clones in both their maternal and paternal pedigrees. This is suggestive of inadvertent selection for heterozygosity in the process of selecting for the best performers, and leads one to suspect that homozygosity may lead to inbreeding depression in black raspberry despite "conventional wisdom" that black raspberries do not suffer from inbreeding depression (Haskell 1960; Ourecky 1975). Dossett (2007) and Dossett et al. (2008) noted that progeny of a wild black raspberry selection from North Carolina, NC 84-10-3, when crossed to cultivars, outperformed and had higher vigor than progeny of crosses among cultivars despite observations that NC 84-10-3 had very low vigor and never grew to be large in the field (Dossett 2007). 
Table 4 Microsatellite alleles (fragment size in bp) at six loci in 'Jewel', 'Haut', 'Allen', 'Earlysweet', 'Black Knight', 'Mac Black' and related black raspberry cultivars, illustrating shared rare alleles and discrepancies in reported pedigrees

\begin{tabular}{|c|c|c|c|c|c|c|}
\hline Cultivar & ssrRhcBA23 & Rubus $275 a$ & Rubus $262 b$ & Rubus $123 a$ & Rubus $126 b$ & Rubus $110 \mathrm{a}$ \\
\hline Bristol & 124,126 & 116,144 & 203 & 158 & 154,168 & 183,185 \\
\hline Dundee & 124 & 116,132 & 203 & 158,188 & 158,168 & 183 \\
\hline Huron & $\mathbf{1 1 2}, 124$ & 128,144 & 203 & 158 & 168 & 169,183 \\
\hline Jewel & 112,124 & 144 & 203 & 158 & 158,168 & 169, 183 \\
\hline Bristol & 124,126 & 116,144 & 203 & 158 & 154,168 & 183,185 \\
\hline Cumberland & 124,126 & 116,144 & 203 & 158 & 154,168 & 183,185 \\
\hline Huron & 112,124 & 128, 144 & 203 & 158 & 168 & 169,183 \\
\hline Haut & 124 & 128, 132 & 203 & 158 & 168 & 187 \\
\hline Allen & 124 & 144 & 203 & 158 & 158 & 183,185 \\
\hline Ebonee & 124,126 & 116 & 203 & 158 & 154,168 & 187 \\
\hline Haut & 124 & 128,132 & 203 & 158 & 168 & 187 \\
\hline Dundee & 124 & 116,132 & 203 & $158, \mathbf{1 8 8}$ & 158,168 & 183 \\
\hline Earlysweet & 124,126 & 116,144 & 203 & $158, \mathbf{1 8 8}$ & 154,168 & 183,187 \\
\hline Black Knight & 126 & 134,144 & 203,209 & 158 & 154,168 & 169,183 \\
\hline Mac Black & 124,126 & 144 & $203, \mathbf{2 0 9}$ & 158 & 168 & 169,183 \\
\hline
\end{tabular}

Names of cultivars with pedigree discrepancies are in bold and are presented in a block with their reported parents and other clones sharing unique alleles. Alleles specifically mentioned in the text are in bold and underlined. Fingerprints for some cultivars (i.e. Dundee, Huron and Haut) are repeated in different blocks for ease of comparison

In this study, NC 84-10-3 was heterozygous at only one of the 21 loci examined (data not shown), suggesting a degree of inbreeding. In fact, the wild genotypes had lower than expected heterozygosity at every polymorphic SSR locus (Table 3). This is not entirely unexpected; subdivision of wild black raspberry populations may lead to an apparent deficiency of heterozygotes and the sampling method violates Hardy-Weinberg expectations. Despite this, the rate of observed heterozygosity (0.21) is less than half that observed in the cultivars (Table 3). The reasons for this are unclear, but may be due to bottlenecking and/or isolation of wild populations from one another. Further sampling from within these populations is needed to better understand the reasons for the observed homozygosity before firm conclusions can be made about the causes.

With the high level of homozygosity in mind, inbreeding depression may be a limiting factor in the field performance of some of these seedlings and their value in breeding may only become evident by evaluating the performance of their progeny from crosses with unrelated germplasm. Further study should be undertaken to examine the impact of inbreeding on black raspberry performance.
In contrast to black raspberry cultivars, wild black raspberry germplasm is diverse. Branch lengths separating the wild genotypes are longer than those separating the cultivars and bootstrap support for groups of wild accessions was poor, indicating that these accessions are more distantly related to each other and that their relationships were not well resolved. The average branch length (distance of shared alleles) separating wild black raspberry accessions in this study was 0.53 , more than twice that of the cultivars. NJ clustering (Fig. 2) illustrates a lack of grouping based on geographical location. For example, wild plants from Nebraska (ORUS 4134) and South Carolina (4114) grouped together as did plants from Maryland (ORUS 3808) and South Dakota (ORUS 4146). A few groups of accessions from neighboring locations were scattered throughout the dendrogram. For example, ORUS 4117 and ORUS 4119 from Clayton, Georgia grouped with each other. However, ORUS 4120 which was collected in the same area, fell in a different cluster. A group of seven accessions from Tennessee cluster together, although other wild accessions from the same areas of Tennessee are scattered throughout the dendrogram (Fig. 2). 
Fig. 4 Principal component analysis (PCA) plot of wild and cultivated black raspberry based on Euclidean distance measured from 21 polymorphic SSR loci and illustrating PCA clustering of wild accessions, black raspberry cultivars, wild accessions clustered with cultivars in Fig. 3, and wild accessions clustering with 'Explorer' in Fig. 2

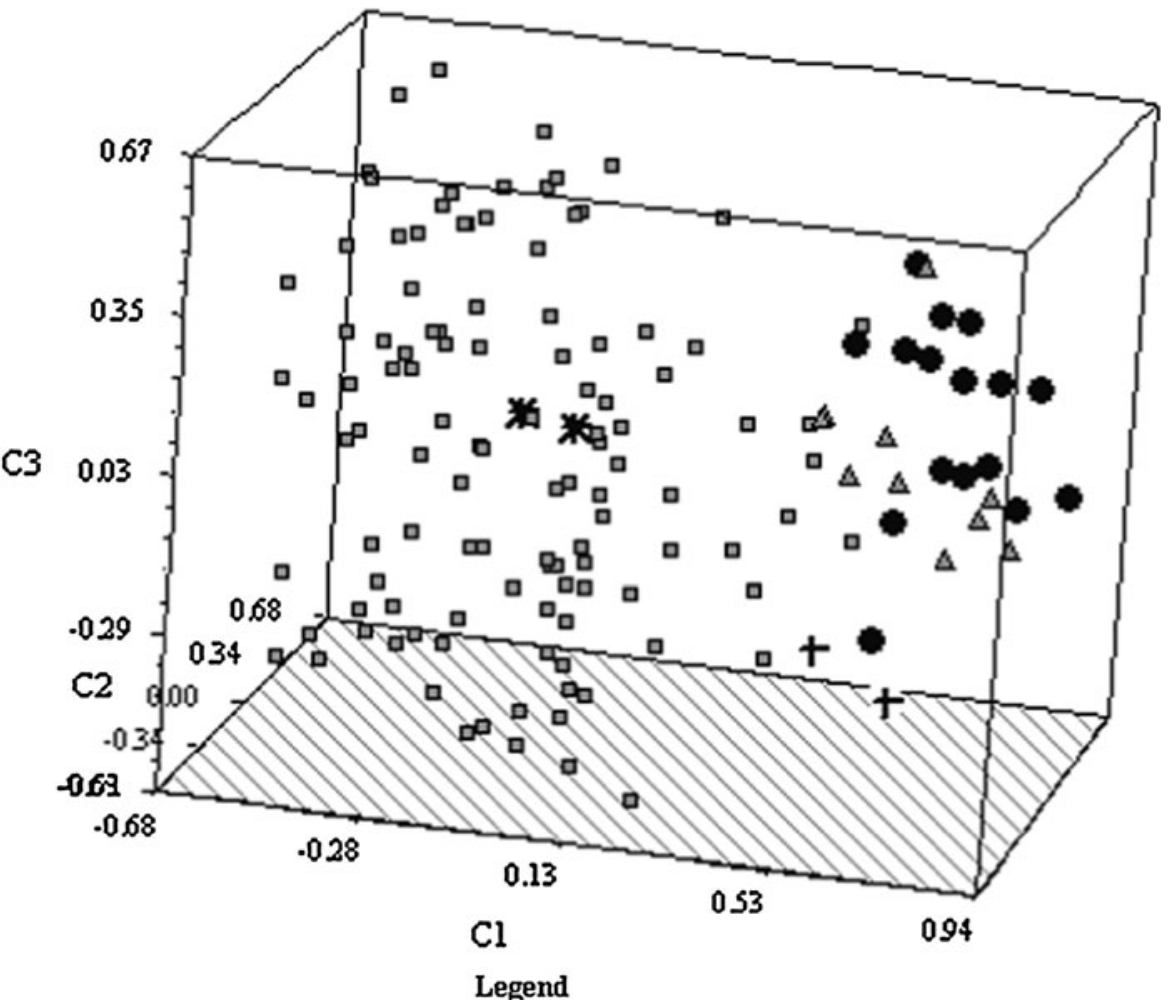

Cultivar

$\Delta$ Wild clustering with cultivars

* $R$ leucodemis

- Wild accession
The deep branching and lack of resolution in relationships among wild black raspberry populations, combined with the general lack of strong regional clusters, may be an indication that black raspberry diversity has not been exhaustively sampled. This also suggests that black raspberry populations may be well-differentiated from each other but not in a strongly geographical manner. Future work investigating the extent of diversity and relationships within and between many of these wild populations should provide insight into the degree of differentiation between wild populations and answer questions regarding whether certain areas of the range contain more allelic diversity than others. This information would be useful for future efforts to collect and preserve genetic diversity in wild black raspberry germplasm.

Principal component analysis did not provide better resolution of the data but did support some of the clusters already observed in the dendrogram. The first three eigenvalues collectively explain $9.6 \%$ of the variance. The first, however, separated black raspberry cultivars from the majority of the wild germplasm (Fig. 4). The wild accessions that clustered with the cultivars (Fig. 2) also grouped with the cultivars on the positive side of this axis. 'Explorer' and the wild accessions that clustered with it in the NJ dendrogram (ORUS 3799 and ORUS 4124) also fell near these on the positive end of the first axis. ORUS 4124 has been noted in field evaluations for larger than average fruit weight, and seed lots of ORUS 3799 and ORUS 4124 segregate for non-glaucous canes (data not shown) that may be an indication of cultivated ancestry. A few additional wild accessions fell in this area, including ORUS 3819, ORUS 3851, and ORUS 3947. The second PCA axis provides some separation between the rest of the black raspberry cultivars and the NJ cluster that includes 'Explorer' and two wild accessions (ORUS 3799, and ORUS 4134). These were located towards the negative end of axis 2 with the rest of the cultivars spread out along this axis. Otherwise, separation of groups along the second and third axes was relatively poor and groups of wild accessions 
were not well resolved. Eigenvalues four and five (data not shown) each explain only about $2 \%$ of the variance, and plotting these does not help further resolve relationships in black raspberry germplasm.

\section{Conclusions}

The vast majority of genetic diversity available in $R$. occidentalis remains untapped in the development of new cultivars. While several cultivars that have not been lost over the last 100 years are reputed to have originated as wild seedlings that were discovered and brought into cultivation because of their superior horticultural traits (Hedrick 1925), it is now clear that the black raspberry cultivars remaining today are very closely related to each other and many of the "wild" selections named as cultivars were probably seedlings of cultivated plants. The few apparently wild accessions that clustered with cultivars have traits such as larger than average fruit, suggesting that they may be the offspring of cultivated plants. Conversely, this also shows that characterization of wild-collected black raspberry germplasm with SSR markers could be a useful tool in the future for identifying whether wild plants with good horticultural attributes are truly wild or are closely related to cultivated material.

Even the most recently developed black raspberry cultivars are not more than a few generations removed from truly wild ancestors. This knowledge, combined with the apparent diversity among wild plants available today, suggests that significant progress in breeding improved cultivars may be possible from a few generations of crossing and selection from between these wild populations without requiring further use of cultivated black raspberry germplasm. The use of this wild germplasm combined with existing cultivars should lead to faster gains for commercially important traits, such as large fruit.

Acknowledgments The authors would like to gratefully acknowledge the technical support of April Nyberg, Theodore Bunch, Wambui Njuguna, and Barbara Gilmore during the course of this project. We also thank Kim Hummer for her role in organizing and participating in the collection trips. We would like to thank the following individuals for contributing seed for this project: W. Anderson (Illinois), M. Bathrick (Pennsylvania), C. Brown (New Jersey), P. Byers (Missouri), T. Cuff (Wisconsin), A. Dale (Ontario), R. Davis (New York), R. Geneve (Kentucky), J. Hancock (Michigan), D. Handley (Maine), A. Jamieson (New Brunswick), K. Kellogg
(Connecticut), J. Lehman (Indiana), T. Leslie (Ohio), H. Love (Tennessee), J. Luby (Minnesota), C. Mauchline (Pennsylvania), R. Moyer (Virginia), G. Nonnecke (Iowa), M. Retter (Indiana), M. Stanton (Ohio), H. Swartz (Maryland), F. Takeda (West Virginia), E. Thompson (Arkansas), C. Weber (New York). This project was supported by grants from the USDA-ARS Northwest Center for Small Fruits Research, the USDA-ARS Plant Exchange Office, and the Oregon Raspberry and Blackberry Commission.

\section{References}

Amsellem L, Dutech C, Billotte N (2001) Isolation and characterization of polymorphic microsatellite loci in Rubus alceifolius Poir. (Rosaceae), an invasive weed in La Réunion island. Mol Ecol Notes 1:33-35

Botstein D, White RL, Skolnick M, Davis RW (1980) Construction of a genetic linkage map in man using restriction fragment length polymorphisms. Am J Hum Genet 32:314-331

Bowcock AM, Ruiz-Linares A, Tomfohrde J, Minch E, Kidd JR, Cavelli-Sforza LL (1994) High resolution of human evolutionary trees with polymorphic microsatellites. Nature 368:455-457

Brownstein MJ, Carpten JD, Smith JR (1996) Modulation of non-templated nucleotide addition by Taq DNA polymerase: primer modifications that facilitate genotyping. BioTechniques 20:1004-1110

Büscher N, Zyprian E, Blaich R (1993) Identification of grapevine cultivars by DNA analyses: Pitfalls of random amplified polymorphic DNA techniques using 10 mer primers. Vitis $32: 187-188$

Castillo N, Reed B, Graham J, Fernandez-Fernandez F, Bassil NV (2010) Microsatellite markers for raspberry and blackberry. J Am Soc Hort Sci 135:271-278

Dossett M (2007) Variation and heritability of vegetative, reproductive and fruit chemistry traits in black raspberry (Rubus occidentalis L.). Thesis, Oregon State University

Dossett M, Finn CE (2010) Identification of resistance to the large raspberry aphid in black raspberry. J Am Soc Hort Sci 135:438-444

Dossett M, Lee J, Finn CE (2008) Inheritance of phenological, vegetative, and fruit chemistry traits in black raspberry. J Am Soc Hort Sci 133:408-417

Dossett M, Bassil NV, Finn CE (2010) Transferability of Rubus microsatellite markers to black raspberry. Acta Hortic 859:103-106

Drain BD (1956) Inheritance in black raspberry species. Proc Am Soc Hort Sci 68:169-170

Galletta GJ, Maas JL, Enns JM (1998) 'Earlysweet' black raspberry. Fruit Var J 52:123

Graham J, Smith K, MacKenzie K, Jorgenson L, Hackett C, Powell W (2004) The construction of a genetic linkage map of red raspberry (Rubus idaeus subsp. idaeus) based on AFLPs, genomic-SSR and EST-SSR markers. Theor Appl Genet 109:704-749

Halgren A, Tzanetakis IE, Martin RR (2007) Identification, characterization, and detection of black raspberry necrosis virus. Phytopathology 97:44-50 
Hall H, Hummer KE, Jamieson A, Jennings S, Weber C (2009) Raspberry breeding and genetics. Plant Breed Rev 32:39-382

Haskell G (1960) Biometrical characters and selection in cultivated raspberry. Euphytica 9:17-34

Hedrick UP (1925) The small fruits of New York. JB Lyon Co, New York

Hitchcock CL, Cronquist A (1973) Flora of the Pacific Northwest. University of Washington Press, Seattle

Hull JW, Britton DM (1956) Early detection of induced internal polyploidy in Rubus. Proc Am Soc Hort Sci 68:171-177

Hummer K, Dossett M, Finn C (2008a) Plant collecting expedition for berry crop species through Southeastern and Midwestern United States, June and July 2007 Part I. USDA ARS NCGR Station Publication, Corvallis

Hummer K, Dossett M, Finn C (2008b) Plant collecting expedition for berry crop species through Southeastern and Midwestern United States, June and July 2007 Part II. USDA ARS NCGR Station Publication, Corvallis

Jennings DL (1988) Raspberries and blackberries: their breeding, diseases and growth. Academic Press, San Diego

Jones CJ, Edwards KJ, Castaglione S, Winfield MO, Sala F, van de Wiel C, Bredemeijer G, Vosman B, Matthes M, Daly A, Brettschneider R, Bettini P, Buiatti M, Maestri E, Malcevschi A, Marmiroli N, Aert R, Volchaert G, Rueda J, Linacero R, Vazquez A, Karp A (1997) Reproducibility testing of RAPD, AFLP, and SSR markers in plants by a network of European laboratories. Mol Breed 3:381-390

Kresty LA, Morse MA, Morgan C, Carlton PS, Lu J, Gupta A, Blackwood M, Stoner GD (2001) Chemoprevention of esophageal tumorigenesis by dietary administration of lyophilized black raspberries. Cancer Res 61:6112-6119

Lewers KS, Saski CA, Cuthbertson BJ, Henry DC, Staton ME, Main DS, Dhanaraj AL, Rowland LJ, Tomkins JP (2008) A blackberry (Rubus L.) expressed sequence tag library for the development of simple sequence repeat markers. BMC Plant Biol 8:69-76

Liu BH (1998) Statistical genomics. Linkage, mapping, and QTL analysis. CRC Press, Boca Raton

Liu K, Muse SV (2005) PowerMarker: an integrated analysis environment for genetic marker analysis. Bioinformatics 21:2128-2129

Lopes MS, Belo Maciel B, Menconça D, Sabino GF, Da Câmara Machado A (2006) Isolation and characterization of simple sequence repeat loci in Rubus hochstetterorum and their use in other species from the Rosaceae family. Mol Ecol Notes 6:750-752

MacPherson JM, Eckstein PE, Scoles GJ, Gajadhar AA (1993) Variability of the random amplified polymorphic DNA assay among thermal cyclers, and effects of primer and DNA concentration. Mol Cell Probes 7:293-299

Nei M (1987) Molecular evolutionary genetics. Columbia University Press, New York

Nybom H, Schaal BA (1990) DNA “fingerprints" reveal genotypic distributions in natural populations of blackberries and raspberries (Rubus, Rosaceae). Am J Bot 77:883-888

Ourecky DK (1975) Brambles. In: Janick J, Moore JN (eds) Advances in fruit breeding. Purdue University Press, West Lafayette, pp 98-129

Schuelke M (2000) An economic method for the fluorescent labeling of PCR fragments. Nature Biotech 18:233-234

Seeram NP (2008) Berry fruits: compositional elements, biochemical activities, and the impact of their intake on human health, performance, and disease. J Agric Food Chem 56:627-629

Seeram NP, Adams LS, Zhang Y, Lee R, Sand D, Scheuller HS, Heber D (2006) Blackberry, black raspberry, blueberry, cranberry, red raspberry, and strawberry extracts inhibit growth and stimulate apoptosis of human cancer cells in vitro. J Agric Food Chem 54:9329-9339

Slate GL, Klein LG (1952) Black raspberry breeding. Proc Am Soc Hort Sci. 59:266-268

Stoner GD, Sardo C, Apseloff G, Mullet D, Wargo W, Pound V, Singh A, Sanders J, Aziz R, Casto B, Sun XL (2005) Pharmacokinetics of anthocyanins and ellagic acid in healthy volunteers fed freeze-dried black raspberries daily for 7 days. J Clin Pharmacol 45:1153-1164

Stoner GD, Wang LS, Casto BC (2008) Laboratory and clinical studies of cancer chemoprevention by antioxidants in berries. Carcinogenesis 29:1665-1674

Tallman PH (2007) Black raspberry plant named 'Explorer'. US Plant Patent 17,727, U.S. Patent and Trademark Office, Washington. D.C

Tamura K, Dudley J, Nei M, Kumar S (2007) MEGA4: molecular evolutionary genetics analysis (MEGA) software version 4.0. Mol Biol Evol 24:1596-1599

Weber CA (2003) Genetic diversity in black raspberry detected by RAPD markers. HortSci 38:269-272

Williams CF (1950) Influence of parentage in species hybridization of raspberries. Proc Am Soc Hort Sci 56:149-156 